Kansas State University Libraries

New Prairie Press

\title{
Racializing The Discourse of Adult Education
}

\author{
Elizabeth A. Peterson \\ National-Louis University, USA \\ Stephen D. Brookfield \\ USA \\ Vanessa Sheared \\ USA \\ Juanita Johnson-Bailey \\ USA \\ Scipio A.J. Colin \\ III,USA
}

See next page for additional authors

Follow this and additional works at: https://newprairiepress.org/aerc

Part of the Adult and Continuing Education Administration Commons

(c) (1) (9)

This work is licensed under a Creative Commons Attribution-Noncommercial 4.0 License

\section{Recommended Citation}

Peterson, Elizabeth A.; Brookfield, Stephen D.; Sheared, Vanessa; Johnson-Bailey, Juanita; and Colin, Scipio A.J. (2005). "Racializing The Discourse of Adult Education," Adult Education Research Conference. https://newprairiepress.org/aerc/2005/symposia/3

This is brought to you for free and open access by the Conferences at New Prairie Press. It has been accepted for inclusion in Adult Education Research Conference by an authorized administrator of New Prairie Press. For more information, please contact cads@k-state.edu. 
Author Information

Elizabeth A. Peterson, Stephen D. Brookfield, Vanessa Sheared, Juanita Johnson-Bailey, and Scipio A.J. Colin 


\title{
Racializing The Discourse of Adult Education
}

\author{
Elizabeth A. Peterson, National-Louis University, USA \\ Stephen D. Brookfield, USA \\ Vanessa Sheared, USA \\ Juanita Johnson-Bailey, USA \\ Scipio A. J. Colin, III, USA
}

\author{
Engaging in Race Talk: Critical Race Theory and Adult Education \\ Elizabeth A. Peterson/National-Louis University epeterson@nl.edu
}

\section{Why engage in Race Talk?}

This symposium began in 2002 as a dialogue between Stephen Brookfield, Scipio Colin

III and me. The circumstances that brought about the dialogue are indicative of the need for a symposium on race talk among educators and even more specifically among adult educators. At the time, Stephen was at Harvard and because of his work there he was asked to contribute an article to the Harvard Educational Review about racializing the discourse of adult education. As a White male Stephen felt strongly that minority voices should included and proposed inviting several African American academics as well-the topic was important enough to warrant a special issue. The editors of HER agreed and Stephen invited Scipio Colin III, Vanessa Sheared, Ian Baptiste, and me to join him in writing articles for this special volume. We submitted our proposals and what ensued over the next months may come as a surprise to some, but to me it serves as an illustration of how unchanged many white academicians are in their belief that it is their right to serve as gatekeepers of ideas and that the authority to create knowledge should rest with a select few. Although the editors of HER seemed enlightened, the Board was not. The Board decided that rather than devote a special issue to the topic, only Stephen's paper would be published and the rest of us were invited to submit a response to his paper. In an instant, we went from being authors of equal standing to mere responders.

I share this story because by telling our personal stories and counter stories we can begin to deconstruct the myth of academia and higher education as the great equalizer and expose the reality often experienced by African Americans and people of color. In doing so, the under current of racism that is so often masked or hidden can be revealed.

\section{Critical Race Theory and Adult Education}

Critical race theorist, Derrick Bell and others suggest that we must assume that racism will always be with us. It seems only natural for adult educators to embrace critical race theoryafter all it expands upon the literature of critical theory which has been tremendously influential in our field. According to Matsudo (1991), critical race theory originated as an attempt to "understand the oppressive aspects of society in order to generate societal and individual transformation.” It is through the telling of counter stories that racism can be exposed. And once racism is exposed, systems can be put in place that may not eliminate racism, but may eliminate the ability of racists and racist behavior to dominate and oppress.

By using critical race theory, adult educators can begin to have authentic discussions of race. This has and continues to be a challenge because institutions of higher education are guided by rules and procedures that were created to establish and maintain a hierarchy based upon rank and position. In order to gain rank, African American scholars have been forced to play by rules that they had no role in designing. African American academicians often find themselves pulled (or pushed) into the role of spokesperson or respondent for every issue that has a racial theme. As a result, their work is seen as being specific or limited and therefore not as rigorous and important as their White counterparts. African American scholars often find that their White 
colleagues do not take their work seriously, and by their authority as peer reviewers, continue to deny minorities opportunities to publish or present. Many others have seen their work gain legitimacy only when their White colleagues embrace it.

We gather at AERC and other research conferences to celebrate our expanding awareness and understanding of these issues, and to address the problems and concerns that are driving our field. But we should also ask, "What has changed if anything as a result of this understanding? Are we really more open as a field? Do we really challenge the structures that exist in higher education that reinforce the status quo? How and in what ways have we made our programs more appealing and accessible to marginalized groups?”

To create an authentic dialogue about race we have to acknowledge the experiential knowledge of faculty and students of color and recognize their legitimacy. These experiences are critical if we are to analyze, understand, and ultimately teach our students about racial subordination and how it impacts our field. We should be asking ourselves several important questions: What untold stories or counter stories need to be shared? Have we really ever talked openly about why the African American Pre-conference started as a forum for African American graduate student research? And, if so many things have changed, why is there still a need for the African American Pre-conference and the other pre-conferences? Why is it still so difficult for people of color to have their work accepted in refereed journals?

By engaging in race talk adult educators have the opportunity to open up a dialogue that would be the first step in creating a scholarly community based upon a true gathering of equals. We cannot continue to pride ourselves for being a field that promotes democratic social change when we do not critically examine how we work within a system that is inherently undemocratic.

\section{References:}

Bell, D. (1992). Faces at the Bottom of the Well. New York: Basic Books.

Delgado, R. (1989). Storytelling for oppositionists and others: a plea for narrative. Michigan Law Review, 87, 2411-2441.

Matsuda, M. (1991). Voices of America: accent, antidiscrimination law, and a jurisprudence for the last reconstruction. Yale Law Journal, 100 1329-1407.

\section{Problematizing Whites' Engagement in Racial Talk}

Stephen Brookfield/University of St. Thomas, Minneapolis sdbrookfield@stthomas.edu

Three responses suggest themselves as to how a White person may try to racialize adult education theory and practice. The first is to take central concepts of adult education (which are usually derived from Eurocentric thought) and to reinterpret these in the interests of a group other than White Euro-Americans. Second, Whiteness scholarship offers an opening to the field's intellectual gatekeepers and theoretical power brokers (most of whom are White) to engage in some critique from within; however, such efforts are fraught with contradiction. Third, White scholars can treat racially grounded perspectives on adult learning and teaching with the same seriousness as they expect scholars of color to treat EuroAmerican perspectives.

Discussions of race should not be solely the province of authors of color. If only authors of color produce articles, books and papers dealing with race then the White majority can easily marginalize the issue as the province only of non-White adult educators, as something 'they' (the generalized non-White 'other' whose only distinguishing characteristic is defined as their lack of Whiteness) should take responsibility for exploring. This effectively keeps racial analysis conveniently (for the White majority) on the periphery. But if White adult educators acknowledge and critique their own complicity in a field racialized in favor of EuroAmericans, and if they engage seriously with racialized analyses drawn from a range of racial perspectives - 
many of which will focus on racism as the salient experience of people of color in a racist country - questions of race and racism cannot so easily be pushed aside by White colleagues.

Focusing on White privilege is crucial work and I support its intent completely. But for Whites to focus exclusively on their own complicity in racism is only one half of the story. I fear that this, once again, positions Whiteness as the thing to be focused on, as the conceptual center. The other project is for Whites to engage seriously with analyses of adult education drawn from other racial group memberships. Whites expect their colleagues of color to be au fait with the Eurocentric intellectual traditions of critical theory, pragmatism, analytic philosophy, positivism, postmodernism and constructivism, all of which assume their position of prominence as the normal, obvious, mainstream modes of analysis in the field because of the power of White EuroAmericans to establish the regimes of truth that apply in a culturally diverse society. In the interests of basic equity, as well as for the intrinsic intellectual and practical enrichment it involves, White adult educators have a duty to immerse themselves in perspectives (such as Africentrism) that racialize the field in the interests of other racial groups.

Well-intentioned attempts by White academics to celebrate non-white intellectual traditions can easily sour till they reek of benign colonialism and false empathy. White adult educators who say they wish to empathize with students and colleagues of color in no way enter their worlds. Even attempts to deconstruct one's White privilege in front of colleagues and students can sometimes serve, paradoxically, to emphasize that privilege. Once again, it places the White experience as the central unit of analysis. There is also the problem that White attempts to broaden the range of adult educational discourses can perversely serve to underscore the implicit legitimacy of Eurocentrism. What Herbert Marcuse called repressive tolerance ensures that an apparent embrace of a different perspective serves only to neuter that same perspective. Broadening the perspectives we review (for example, including a module on "The Africentric Paradigm" in a course on "How Adults Learn") seems to give equal weight to radical or alternative ideas, when in fact placing them alongside mainstream ones can easily dilute their oppositional qualities.

As long as the dominant, mainstream perspective is included as one of several possible options for study, its presence inevitably overshadows the minority ones, which will always be perceived as alternatives but never as the natural center to which one should turn. Irrespective of the educator's viewpoint (which may be strongly opposed to dominant ideology), the mere inclusion of that ideology as one option ensures its continued dominance. This is because the mainstream ideology is so pervasive that it operates at a preconscious level shaping our responses to alternatives that are proposed to it. The only way to promote real tolerance - liberating or discriminating tolerance in Herbert Marcuse's terms - is to deny learners the chance to consider mainstream perspectives as one possibility among many. Marcuse urges educators to practice true tolerance by allowing students exposure only to alternative views and dissenting traditions. The logic of liberating tolerance would require an immersion only in a racial or cultural tradition that diverged radically from mainstream ideology; for example, an adult education graduate program that allowed only the consideration of Africentric ideas and perspectives. The logic of repressive tolerance holds that, as long as Africentrism is considered as one of many possible perspectives, including Eurocentrism, it will always be positioned as the marginal alternative to the White supremacist center.

\section{A Perspective from the Margins: The Intersection of Race and Gender} Vanessa Sheared/San Francisco State University vsheared@sfsu.edu

To live in the margins, yet operate in the center has become my mantra as a Black woman educator, administrator, mother, daughter.... In order to understand what it means to live in the margins as a Black African American womanist adult educator, I believe that an examination of who one is in relation to race and gender- two factors that can cause one to be in the margins or 
marginalized - are helpful to the discourse in adult education. Dialogue about race and gender should begin with an examination of the terms being used to describe how one sees one's self. So, I begin with me the author, someone who lives in the margins, yet operates in the center. First, I use the term Black African American to first depict my race and geographic location, and the term womanist to depict my gender as a way to situate myself within the context of this analysis. Race, although socially constructed, is a term used to help identify and classify human species as it pertains to the color of our skin, whereas gender specifies the biological and social distinctions between the male and female species. These are just two of the intersecting points of reality that shape who we are and help us make meaning out of the words we read, speak, write and live - our stories.

As an African Centered womanist adult educator, I believe that the intersection of race and gender should be considered in creating an analysis about the ways in which people come to interpret, understand and make meaning out of the words they speak and the world in which they operate, whether they are in the margins or in the center. To be in the center suggests that one has power and control over one's economic, political, socio-cultural and historical contexts. So, how does one living in the margins begin to negotiate and operate in the center with respect to their race and gender? And how can they do this without becoming marginalized? Using Freire's (1990) ideas in Pedagogy of the Oppressed and hooks (1994) perspectives in Teaching to Transgress, as a process for uncovering, discovering and evolving as a researcher, teacher and practitioner from the margins, I offer a portion of my lifestory.

As a female African American child, growing up in the south, I somehow understood at a very young age that there were certain places that I could travel or visit in my racially segregated community. For instance, during the late 1950's and early 1960's, living in a small town, called Bastrop Louisiana, I as well as the other African Americans in this town were prohibited from going through the front doors of the movie theatre, were not allowed to drink out of the water fountain on the square, and had to go to the side of the local ice-cream shop to purchase ice cream. At the time, I did not understand that I was living in the margins - however, I did understand at the age of six that as a result of the color of my skin that I was not allowed to go into or through certain doors. Although I was a young girl, it was not my biology or my gender that surfaced initially as a problem, it was the color of my skin- my race that had the greatest significance on how I viewed myself. Later in life, I came to understand that this was my first foray into what it means to live in the margins, as well as how race in particular effects how others view you and the impact that this interpretation might have on how we view ourselves.

In addition to this, as I grew older, I began to notice in the literature, in the media, and in the work force that white women were defined by the roles they played for instance, as mothers, daughters, lovers, nurturers and caretakers of others. Feminist, Africentric Feminist and Womanist scholars have offered critical analyses of the intersection of race and gender and how the aforementioned roles along with race and gender influence where one is situated in society, and the amount of power one might derive from where one is located in society. These experiences as well as analyses further impacted the ways in which I began to view the role of living in the margins versus being marginalized.

To live in the margins, means that one is on the edge of the whole - not really considered as having a meaningful place within, but clearly seeing and ultimately understanding what one can become, if one is allowed to enter into the primary circle or discourse. Just as hooks (1984) notes in the preface to Feminist Theory: From Margin to Center,

This sense of wholeness, impressed upon our consciousness by the structure of our daily lives, provided us an oppositional world view- a mode of seeing unknown to most of our oppressors, that sustained us, aided us in our struggle to transcend poverty and despair, strengthened our sense of self and our solidarity. (pg. ix)

Being on the margins can help you interpret the world, whereas being marginalized "has a way of making people question who they are so that they soon begin to believe that others' perceptions 
of the "self" are more accurate than the perceptions formed by themselves" (Sheared, 1998, pg. 41). So, as a child I thought something was wrong with me, and that I had to find a way to overcome this deficiency. As I later discovered in my earlier research on women and welfare (Sheared, 1998),

Marginalization is an extension of oppression because, if people no longer see themselves as being significant, then their political, economic, and socio-historical agenda is nullified. In becoming nullified, they become the oppressed. (pg 41)

Although I did not fully understand what it meant to be in the margins or what it meant to be marginalized as a young female child, I am beginning to understand that being in the margins does not mean that one has to be marginalized. How, then can those in the margins resist becoming marginalized? I have come to understand that, while being in the margins suggests that one is on the edge, being on the edge is not necessarily a negative thing. This is the first step. By telling one's story through an examination of the intersections between race and gender, we can become critically conscious of the discourse and images used to shape our thinking. As our stories unfold, we should also address other factors (e.g. language, religion, culture, etc.) that effect how we see ourselves. The more we engage in this process with others, the more likely it is that we will begin to change the way we read, think, and interact with one another in varying contexts.

\section{References}

Freire, P. (1990). Pedagogy of the Oppressed. New York: Continuum Books. hooks, b. (1984). Feminist theory, from margin to center. Boston, MA:South End Press. hooks, b. (1994). Teaching to Transgress, practice of freedom. New York: Routledge. Sheared, V. (1998). Race, gender, and welfare reform, the elusive quest for self determination New York: Garland Publication.

Matters of Race in Adult Education Juanita Johnson-Bailey/University of Georgia jib@coe.uga.edu

Despite the stated good intentions, adult education has not succeeded in accomplishing the goals of empowering those lacking basic skills and in bringing all citizens to the table. Indeed the barriers that have crippled the field's goals, including racism, classism, sexism, and ethnocentrism continue to divide and disable society in general. There are many avenues through which societal issues enter our adult education practices. Research journals and texts, programs and class curricula, student enrollment, student interactions, and faculty makeup are the most salient foci in discussing how our adult education system operates. As educators how can we best grapple with our dilemma of who we are serving, and how can we foster a teaching and learning environment of equity and empowerment? I believe the answer for practitioners lies in our dayto- day teaching and learning transactions.

Many variables drive the teaching and learning transaction. This paper examines one of these issues: race. In doing so, my intention is not to suggest that race is the most significant or important of the variables. Since power operates in similar ways to disenfranchise women, people of color, gays, and the disabled, race is therefore offered as a salient and representative constant that can be used as an instrument with which to make comparisons and evaluations.

In examining race it is necessary to establish a working definition that is applicable to American society. Race is a social construct (Gregory \& Sanjek, 1994; Winant, 1994) that is used to organize people into groups according to their physical appearance. In addition racial clustering encompasses tacit ideas concerning the intellectual, physical, and moral tenets of group members. While scientists agree that definitive racial codification is based on a nebulous set of physical characteristics, such classification systems stand as primary ways in which we identify 
people in our Western society. Admittedly, no matter how ambiguous racial classification may be, race profoundly affects how a person functions is this society (Giroux, 1997; McIntosh, 1995). Therefore to be Asian, African American, Hispanic, Native American, or White in our Adult Education classroom carries a different meaning with each classification. Yet, in the field of Adult Education, we frequently ignore these arbitrary distinctions by proceeding with generic praxis, literature, and discourses.

When we talk of race in contemporary North American societies, we refer primarily to people of color. When we speak of race as educators, we use the same frame of reference and typically refer to every group except Whites, foregoing naming them and thereby giving the semblance of normalcy to whiteness and according whiteness the power to determine and define all other races. This seeming innocuous act permits whiteness to remain the unseen perfect entity against which all other groups are measured (Fine, Weiss, Powell, and Wong, 1997).

When we participate in programs or classes as students, instructors, or planners, we bring the historical weight of our race with us. It matters little whether we intentionally trade on or naively try to discard the privileges, the deficits, or standpoints of our racial statuses. Such ranks, authorizations, honors, suspicions, and stereotypes can not be cast aside. They are accrued in society's invisible hierarchical banking system of trading and bartering according to designated racial rankings. We rank order groups according to their alleged contributions and participation in maintaining society. We value one group over another in terms of tax dollars generated and in turn allocate that group greater or fewer resources to support basic needs, including education. The implicit understanding that those who have more in a capitalistic order will receive more translates directly into how educational dollars will be disbursed.

Despite the importance of race to educational access, disenfranchisement and enfranchisement as related to education and group membership are rarely discussed in tandem. When the poor and under-educated are the center of the discourse what is absent in discussions is the norm of enfranchised learners and privileged students who remain the measure of comparisons. Researchers often present data on one group and represent the other group in silent absentia. However, in order for any discussion on adult education to be complete, the examination must not only give statistics on who participates, how they are instructed, and how they learn, but must also include who does not participate or who seldom participates, how they are instructed, and how they learn.

What we must understand and admit as a field is that when information is presented on the dominant White majority, this seeming impartiality empowers one group while disempowering others. When data on Whites is always present, it is logical to assume that Whites have done the most or certainly have made the more significant contributions.

While educators and practitioners acknowledge race as a variable that affects teaching and learning, they do so without fully acknowledging how race shapes the ways in which we plan and practice. We frequently use terms like underprivileged students, at-risk learners, and minority students to identify and label certain populations. However, we do not expand our thinking to understand how the life conditions of underprivileged learners play out in their everyday classroom circumstances. As practitioners we must reflect on how race impacts our teaching environments and how we manage these intersections. How do such learners fair in our classrooms and programs? How does our thinking about these learners affect our practice and our field?

Finally, the struggle to promote equity in the learning environment through the way we teach or facilitate is ongoing. No matter how far one travels, one never reaches a final destination of establishing a teaching and learning space that is safe and fair. As bell hooks reminds us, power continuously co-opts (1989). Therefore being satisfied with one's practice sanctions a sense of false comfort. Being a person of color or an empathetic majority member does not provide an automatic understanding or offer "true" solutions for managing a racially diverse setting in such a way that race is never an impediment to the exchange of knowledge. When 
practitioners no longer struggle to find texts that include different voices and views, when they fail to establish a curriculum that is inclusive and responsive to diversity, or when they do not challenge research that accepts the hegemonic influence of the culture, then they must assuredly be part of the problem.

\section{References}

Fine, M., Weiss, L. Powell, L. C., and Wong, L. M. (1997). Off White: Readings on Race, Power, and Society. New York: Routledge.

Giroux, H. A. "Rewriting the Discourse of Racial Identify: Towards a Pedagogy and Politics of Whiteness.” (1997). Harvard Educational Review, 67(2), 285-320.

Gregory, S., and Sanjek, R. (Eds.). (1994). Race. New Brunswick, NJ: Rutgers University Press. hooks, b. (1989). Talking back: Thinking feminist, thinking black. Boston: South End.

McIntosh, P. "White Privilege and Male Privilege: A Personal Accounting of Coming to See Correspondences Through Work in Women’s Studies.” (1995). In M. L. Anderson and P. H. Collins (eds.), Race, Class, and Gender. Belmont, CA: Wadsworth.

Winant, H. (1994). Racial Conditions: Politics, Theory, Comparisons. Minneapolis: University of Minnesota Press.

\section{“Through the Eyes of Ethiopia:” The Africentric Paradigm}

Scipio A.J. Colin, III/National-Louis University scolin@nl.edu

... the history of the world is the history, not of individuals, but of groups, not of nations, but of races, and he who ignores or seeks to override the race idea in human history ignores and overrides the central thought of all history." W.E.B. DuBois (1897). The Conservation of Races. Speech Before the American Negro Academy.

The Africentric Paradigm is an analytical and interpretive frame that is utilized by scholars of the African Diaspora who choose to ground themselves in this intellectual tradition. We engage in the analysis of the impact of sociocultural and intellectual on members of the African Diaspora, which we believe are sanctioned and perpetuated by sociocultural systems.

This paradigm/worldview is culturally grounded/African Centered in that the placement of Africa and the African Worldview is the conceptual center of any sociocultural and sociohistorical analysis of African peoples. As such, this paradigm reflects a particular value system, out of which emerges philosophical frames, conceptual constructs and theoretical formulations that can be used by educators of adults in the development of relevant educational programs and activities. It is as Asante (2003) states an

“ideology of heritage... a philosophical perspective associated with discovery, location, and actualizing of African agency within the context of history and culture. By agency is meant an attitude toward action originating in African experiences.” (pg. 3)

It is this paradigm that allows me to be both "agent and actress " personally and professionally, and it conceptually grounds me in an intellectual tradition that reflects the dual purposes of liberation, cognitively and affectively. 


\title{
AN AFRICENTRIC SCHOLARS CREDO Colin (1999)
}

\author{
MOTTO: I WILL NOT EQUIVOCATE, I WILL NOT RETREAT A SINGLE INCH, AND I \\ WILL BE HEARD. The American Negro Academy (1897)
}

I BELIEVE in the placement of Africa and the African Worldview in the center of any sociocultural and sociohistorical analysis of African Peoples I the African Diaspora).

I BELIEVE that racism is the primary impact factor regarding the lives and liberties of African Peoples.

I BELIEVE that the study of African History will provide the sociocultural and intellectual antecedents for a current understanding of this intellectual tradition.

I BELIEVE that members of the African Diaspora need to reclaim and regain a sense of self ethnic pride and cultural identity through the serious study of an accurate African and Diasporic History.

I BELIEVE that Womanist Pedagogy is the appropriate analytical and interpretative frame for understanding and confronting the issues of gender relative to women of the African Diaspora.

These beliefs are reflected in my commitments to the field of Adult and Continuing education and to our Research Scholars, thusly:

I AM committed to the eradication of the impacts of sociocultural and intellectual racism in all spheres of life relative to members of the African Diaspora through Africentric Research /Africology and culturally grounded education.

I AM committed to the inclusion of this intellectual paradigm in Adult Education Graduate Curricula for the benefit of ALL of our Research Scholars. The exclusion of this knowledge base not only locks students of African Descent out, but locks others in.

(pg. 1)

As a member of this professorate, this is what I stand for, this is what I believe. Clearly, there remains a question for others to answer, if they so choose: How and in what ways are you going to facilitate the authentication of Students of African Descent in our graduate programs?

\section{References}

Molefi Kete Asante. ( 2003). AFROCENTRICITY: The Theory of Social Change. Chicago, Illinois: African American Images.

Scipio A. J. Colin, III (1999). Through The Eyes of Ethiopia: Africentrism and Culturally Grounded Research. Unpublished Manuscript, National-Louis University, Chicago, Illinois. 